\title{
Defining the public domain in economic terms - approaches and consequences for policy
}

\section{Kristofer Erickson}

University of Glasgow, CREATe - the Centre for Copyright and New Business Models in the Creative Economy, kristofer.erickson@glasgow.ac.uk

DOI: http://dx.doi.org/10.5324/eip.v10i1.1951

(cc) BY

This is an open access article distributed under the terms of the Creative Commons Attribution 4.0 International License, which permits unrestricted use, distribution, and reproduction in any medium, provided the original author and source are credited.

Stimulating innovation and growth in the so-called 'creative economy' is a current policy objective for national regulators. One policy lever that can be applied to the creative sector is intellectual property. For example, regulators may alter the scope or term of protection offered by copyright law. Increased copyright protection limits the size of the public domain by restricting access to and use of cultural expressions. Opposition to expansion and further enclosure of the cultural public domain was previously articulated in terms of access to a commons of information. Following the Hargreaves Review of Intellectual Property in 2011, copyright reform in the UK context has been increasingly framed in terms of economic policy objectives. This paper reviews two economic approaches which shape how researchers and policymakers discuss the public domain in debates about IP reform: an economic welfare approach which weighs increases in producer and consumer surplus under different policy configurations and an economics of innovation approach which considers the value of the public domain as a reservoir of ideas for innovators and firms. I argue that economic definitions of the public domain should be augmented by a consideration of the democratic requirements of freedom of expression and access to information. The consequences of this refiguration of the public domain for the public interest and access to information are discussed.

Keywords: Copyright, IP, public domain, economic welfare, innovation, public interest, media regulation

\section{Introduction}

The existence of a public domain could be said to serve an essential purpose in democratic society by providing a common reservoir of information upon which an informed citizenry can make choices. Intellectual property law is one mechanism by which societies regulate expressive spaces which can fulfil the role of a public domain. The global website Wikipedia is one example of a public domain resource which organises voluntary contributions of information and makes the resulting material available under a free and open license to all users. Wikipedia's copyright license is designed to ensure that information which it publishes in the public 
domain cannot be privatised or restricted (Heald et al. 2015). Prior to the arrival of internet platforms like Wikipedia, encyclopaedias were sold by specialist publishing companies to individuals and libraries for a fee, which included a profit margin above the expense of gathering the information and printing it in a bound book. The 'rents' which copyright owners may charge for their information products arise from the time- and scope-limited monopoly rights granted by copyright law. When the term of protection in a copyright work ends, it is said to fall into the public domain where, it is traditionally theorised, profit seeking will be hindered (Landes \& Posner 1989; Heald 2014). Promoting a vibrant public domain is thus a normative project with both political and economic justifications. In a website like Wikipedia both aspects are simultaneously present - Wikipedia disables profit seeking by private encyclopaedia vendors and enables democratic participation by spreading information and knowledge which forms the basis of political action.

Recently, the balance has shifted to favour an economic justification for the public domain, rather than a political one, in debates about the appropriate limits of copyright law. This marks a recent shift since the turn of the millennium, when a substantial amount of legal theory was focused on identifying whether proliferating private property rights in information constituted a 'new enclosure' (Benkler 1999; Boyle 2003; Rose 2003; Lessig 2004). Broadly, this literature was concerned with the effects of extending private property rights into domains (culture, biology, social relations) that were not previously governed by intellectual property. Justifications for preserving the public domain were framed in terms of preserving an informational commons. The negative consequences of enclosure were argued to include reduced participation in democratic communication (Boyle 2003: 47), an erosion of the distinction between the private sphere and the market (Lessig 2004: 79) and social dislocation equivalent to the removal of freeholders from common land (Boyle 2003: 35).

Protests about an eroding commons did not appear to halt the expansion of intellectual property rights in information. ${ }^{1}$ For example, the European Union Directive 96/9/EC on the legal protection of computer databases created a set of new rights in collections of information. The Database Directive, which was fully adopted by all EU Member States by 2002, grants protection in databases where there has been significant investment by the creator in 'obtaining, verification or presentation of the contents'. ${ }^{2}$ Copyright protection in Europe was also further expanded in this period. Directive 2011/77/EU extended the copyright term in sound recordings from 50 to 70 years after first publication. ${ }^{3}$

As intellectual property rights have expanded, resistance has begun to focus on inconsistencies in the economic rationale for expansion of IP law. The language of reform shifted gradually toward protection of the public domain in economic terms, using economic evidence. A 2006 report prepared by Andrew Gowers and commissioned by UK Chancellor of the Exchequer Gordon Brown articulated copyright reform in terms of economic growth alongside fair and equitable access to information. For example, Gowers justified the need to limit the reach of copyright with exceptions as follows:

Exceptions to copyright exist to rectify two problems. The first is transaction costs. There are uses of copyright protected material for which it would be too costly and too time consuming to clear the rights, for example in a book review. Second, there are issues of equity. [...] In the absence of 
exceptions, copying a text into Braille would be infringing copyright. To deal with such cases 'fair dealing' legislation exists, which creates a space in which it is not illegal to infringe copyright. (Gowers 2006: 14)

A subsequent 2011 report commissioned by David Cameron's coalition government and authored by Professor Ian Hargreaves pondered many of the same reforms. Hargreaves framed the need for policy reform in terms of the economic justification for copyright: 'Could it be true that laws designed more than three centuries ago with the express purpose of creating economic incentives for innovation by protecting creators' rights are today obstructing innovation and economic growth?' (2011: 5).

This paper explores the consequences of the shift from perceiving the public domain as an 'information commons' to perceiving it as an instrumentalised engine of economic growth. On one hand, it would appear that using the language and techniques of economics to assign a value to the public domain is a powerful tool for reforming IP policy. By comparing the uptake and use of goods in the public domain with those in private ownership, economists can demonstrate that ideas and expressions in the public domain have 'value' and should therefore be protected from privatisation. Empirical research can demonstrate that, absent property rights, there remain incentives for users to appropriate and commercialise ideas in the public domain, keeping them in circulation. By enabling comparison of cultural practices using universally accepted methods of valuation, the tools of economics make the task of convincing national policy makers easier.

On the other hand, changing the metrics by which we assign value to the public domain will impact the kinds of protections which are appealing to policy makers and consequently will alter the shape of the public domain. It may no longer be the case that we face a 'tragedy of the anti-commons' in which the proliferation of private rights and enclosure of the commons threaten innovation. Instead, in a rush to balance IP policy to promote economic goals, we may instrumentalise the public domain as a driver of growth, to the detriment of other public interest considerations. In the following section, I review two common approaches that economists have used to evaluate the effects of intellectual property: (i) an economic welfare approach which calculates consumer and producer surplus under different configurations of IP, generally concerned with the monopoly rights granted to creators, and (ii) an economics of innovation approach which considers the ability of organisations, individuals and firms to generate and appropriate value from new knowledge and ideas. I contrast these two approaches with a public interest justification for the public domain which arises from the right to freedom of expression and the fundamental balancing of access against incentives in IP law. The article concludes with an overview of the way that public interest justifications for the public domain focused on democratic values differs from conceptions supported by economic arguments.

\section{Copyright and economic welfare}

In their influential analysis of the economics of copyright, Landes and Posner (1989) characterise the provision of creative works as a traditional public goods problem. Artistic expressions that might be protected by copyright can be thought to be public goods because in practicality they are non-rival and non-excludable. 
When an artist creates a work such as a book of fiction, a photograph, or an interactive video game, he or she invests resources in its creation. However, once created and revealed to the public, the expression might be copied and circulated at very low marginal cost for each additional copy. Because of the distributed nature of recording technology, this copying can take place outside of the control of the creator or rightsholder. Absent a way to control the circulation of a creative product, incentives to create will be low. In order to ensure that new artistic works are produced, society offers a legal monopoly which solves the incentives problem of artistic expression by granting the creator the ability to limit access to the work. However, offering these incentives results in deadweight loss because creators have the means to set marginal prices above marginal costs, excluding some potential consumers (Yoo 2007: 646). The cost to society is a reduction in the number of copies of a work which freely circulate, but the trade-off should be an increase in the amount of new creative works. The purpose of copyright for Landes and Posner is therefore to 'maximize the benefits from creating additional works minus both the losses from limiting access and the costs of administering copyright protection.' (Landes \& Posner 1989: 326).

In order to calculate the optimal balance of copyright protection, Landes and Posner consider the effect of different levels of copyright protection on economic welfare, defined as the sum of consumer and producer surplus (1989: 339). Consumer surplus refers to the additional value that a consumer enjoys above the market price (which in a competitive market corresponds to the marginal cost of production) and the amount they would be willing to pay for the good (Scotchmer 2006: 37). Producer surplus is the difference between the cost of producing a good and the price that the producer actually receives in a competitive market. When Landes and Posner consider both consumer and producer surplus in a single market for a single creative work, the authors assert that increasing the protection granted by copyright will reduce total welfare (1989: 340). That is because as copyright protection increases, it also increases the cost to produce the original single work (additional creative investment is required in the absence of permitted borrowing). The cost to produce copies is also increased with greater protection, increasing the price and reducing access to the work by members of the public who are not willing to pay the higher price demanded by the producer under strict copyright protection.

However, access to an individual work is not the only concern in the calculation of the welfare effects of copyright (although access may have other implications, which are discussed below). In the basic economic welfare model proposed by Landes and Posner, society also considers the effect of copyright protection on the quantity of new works created, against which access to any given work must be weighed. When the authors include the effect of copyright protection on the creation of new works in their economic model, they find that overall welfare is increased, because the profits earned by creators stimulates the creation of a greater number of new works, up to a point. Consumers' access to any individual work is reduced due to higher price and higher marginal costs of copying. This is the tradeoff between providing an economic incentive to creators and enabling wider access to works.

The public domain figures in this model as having an effect on the cost of production of new goods. Because creators rely to a certain extent on ideas and inspiration which originate from their predecessors, the strength of copyright affects 
not only consumers of their work, but their own creative process. If regulators set the level of copyright protection too high, Landes and Posner argue, ' $t$ t] he effect would be to raise the cost of creating new works - the cost of expression, broadly defined - and thus, paradoxically, perhaps lower the number of works created.' (1989: 332). This, they argue, provides a sound economic efficiency argument for the idea/expression dichotomy which traditionally underpins copyright doctrine. According to this principle, some aspects of a work should never be protectable by copyright because the result would be inhibitive to new creativity. Examples of unprotectable ideas include elements of genre, meaning, or basic scientific knowledge underpinning a work.

A considerable amount of recent scholarship has examined the relationship between copyright protection and access to information (works) from an economic welfare perspective. For example Peitz and Waelbroeck (2006) have analysed digital piracy in terms of economic welfare, finding contradictory results depending on assumptions made in economic models about the heterogeneity of consumer demand and willingness to copy, as well as for models which add complexities such as network effects and indirect appropriability. Broadly, they find that digital piracy reduces welfare for copyright holders, but may increase net social welfare under certain assumptions. Bechtold et al (2016) have observed sequential innovation in an experimental setting, to assess whether copyright protection in derivative works is adequately balanced to promote optimal levels of re-use of original copyright expressions. The authors find that creators do not respond rationally to property rights incentives and instead appear to exhibit personal preferences in their choice to creatively re-use existing expressions. The implication for copyright policy is that over-protection of original works may not be welfare optimal, as it will dissuade productive re-use that could not otherwise proceed.

Empirical evidence from the sale of media goods suggests that current terms of copyright protection may be unnecessarily lengthy, preventing optimal exploitation of works which are under protection but not in sufficient demand to prompt commercialisation (Buccafusco \& Heald 2013; Heald 2014). Reducing copyright protection on these works (expanding the public domain) may consequently have the reverse effect predicted by Landes and Posner, that is, lead to greater availability of works for consumers without reduced incentives to create. For example, Buccafusco and Heald (2013) have studied the commercial availability of audiobooks and found that books in the public domain in the USA published between 1913-1922 are more likely to have an audiobook available. This empirical finding contradicts the theory advanced by Landes and Posner suggesting that private investment will be lessened without property right protection. On the basis of economic underutilisation, Buccafusco and Heald (2013) argue that 'If the argument for copyright term extension turns on the need for incentives to reproduce older works or create derivative works from them, then existing empirical evidence suggests that term extensions are not needed and are probably counter-productive.' (2013: 30).

Alternative analyses of out-of-copyright goods have sought to calculate welfare effects of expanding or contracting the public domain. Heald et al. (2015) have attempted to empirically measure the effect of availability of public domain imagery on producer and consumer surplus using data on page-level Wikipedia visitorship. The authors constructed a sample of biographical subject pages on the 
encyclopaedia platform, spanning a period of time which included in-copyright and out-of-copyright public domain photographs. Subject pages accompanied by a freely available public domain image were found to draw an additional $22 \%$ usage. Based on industry standard advertising rates for equivalent commercial websites, the authors calculated an increase in consumer surplus for the availability of public domain photographs of between USD \$208M and USD \$232M annually (Heald et al. 2015: 29).

In sum, a welfare economics approach to copyright policy considers the impact of property rights on the quantity of new creative products, investment in the creation of those products, and on the ability of consumers to access those works. The welfare economics approach uses consumers' 'willingness to pay' (WTP), either directly or indirectly measured, in calculations of the optimal pricing and level of copyright protection. For Landes and Posner, the optimum level of copyright protection, and consequently the size of the public domain, is a function of the cost of expression for new works. That is, the public domain should exist in order to reduce the cost of creativity for derivative or later works, but it should not be so vast as to allow copies to compete with original goods. Other scholars such as Ronan Deazley have offered a legal theoretical articulation of this position, that copyright protection ultimately exists to fill the public domain with works (e.g., the protection to the author granted by copyright allows her to reveal the work to the public rather than only circulate it privately) (Deazley 2007). In Deazley's conception, the emphasis is on maximising the quantity of works which ultimately end up in the public domain; Landes and Posner are concerned with determining the most efficient level of copyright protection to promote the greatest amount of new creations in a single moment. A welfare economics perspective can take account of the benefit of access to the knowledge contained in the public domain by balancing the cost of creation and the market for in-copyright goods.

\section{Economics of innovation}

The economics of innovation seeks to understand the factors which prompt activities deemed 'innovative', at the scale of the nation, the city/region, or the individual/firm. Innovation, like creativity, can be characterised as a public good. Firms may pursue innovation $\mathrm{R} \& \mathrm{D}$ to achieve a competitive advantage, but unless they possess means of appropriating and profiting the value of that innovation, traditional economic theory suggests that underinvestment will occur (Teece 1986; Towse 2014: 16). Because an idea can spread rapidly and be adopted by free-riding market competitors, the incentives for an individual firm to invest in basic scientific research is low. A market failure condition may arise, leading to policy interventions which may include changes to intellectual property laws to protect innovators' discoveries. As a result of the public goods qualities of innovative ideas, much innovation takes place in collaboration between private interests and public institutions. Governments offer innovation incentives in a variety of forms, such as through tax incentives, IP rights, government grants and prizes, or patronage from foundations (Scotchmer 2006: 14).

Even assuming that intellectual property protection is effective, once innovation takes place there may be further barriers to efficient economic exploitation. Pricing an innovation is difficult, and can result in failure to transact (for example when 
licensing a patent to a manufacturer). This is because neither the seller nor the buyer knows precisely what ownership rights to an innovation are worth (Scotchmer 2006: 36). Pricing and market failure are important considerations in the literature on innovation, concerned with 'unlocking' innovations from the bounds of property rights which may not be fully exercised. For example, in creative goods, Buccafusco and Sprigman (2011) have demonstrated the existence of an endowment effect, in which the amount that an owner or creator of a good is willing to accept to part with it, is higher than what others would be willing to pay. An endowment effect in creative production could result in underutilisation of innovations because holders of a copyright would be unable to come to an agreeable price with a potential licensee, reducing the circulation of an innovation. On the other hand, intellectual property rights may alleviate the inability to transact under certain conditions (for example, where reliable signals for consumers to gauge the quality of goods are lacking, such as in online transactions). Erickson et al. (2015) have studied the role of intellectual property re-use in attracting crowdfunding for media goods. The authors find support for the role of pre-existing intellectual property rights in attracting backers to an untested good where the buyer has low or imperfect information about the seller and the goods offered. The effect of quality information provided to potential consumers via IP is detected for two types of products: those that incorporate inputs from in-copyright works and those that reuse public domain works. The authors calculate a significant uplift to innovator rewards for re-use of public domain materials which is comparable to the uplift measured for licensed copyright inputs.

The goal of promoting innovation can support arguments for protecting or expanding the public domain. The grant of additional intellectual property rights is not always determined to be an appropriate policy solution, for example in industries that have formed effective self-regulating bodies or other norms-based systems (Bechtold 2013; Alexy \& Reitzig 2013). Additionally, legal protection may simply lag behind innovation in markets where property rights were not previously established. A puzzle for economics and management research has been to explain the presence of innovation in the absence of strong IP rights or other means of appropriating value from innovations in these new activities. The gap in understanding was made particularly acute by the appearance and rapid rate of adoption of Free and Open Source Software (FOSS) products since the 1990s. As described by Eric Raymond (1998), the community of developers which sprang up around the Linux operating system was 'open to the point of promiscuity', surprising both the pre-existing open source software community and commercial providers (Raymond 1998). But, two lessons from free and open source software development seemed to Raymond to help explain its success. The first observation was that treating users as co-developers led to rapid code improvement and effective debugging. A second observation was that by releasing imperfect code early and often, iteration was possible and customer improvements could be incorporated. Neither of these innovation activities depends on strong intellectual property protection, and in some cases they are improved without it.

Another challenge for economists and innovation scholars became how to explain the investment of private resources in collective open source projects, where others could free ride on the innovation (von Hippel \& von Krogh 2003; Alexy \& Reitzig 2013). Theoretical and empirical research suggests that even in areas where 
intellectual property rights are possible to apply and routinely granted, it may still be economically efficient to reduce the level of protection for new innovations. For example, Harhoff et al. (2003) have used a game theoretic approach to model the decision by multiple firms to incorporate free and open innovation for a new product, when competing firms may also do so. The strategic decision to openly reveal an innovation, which the authors call 'voluntary information spillover', may occur when the revealer possesses complementary assets which reinforce competitive advantage, or when network effects arising from wider adoption of the innovation would confer larger benefits to the firm.

The economics of innovation approach can demonstrate empirically that there are sound reasons to limit intellectual property rights in certain circumstances if the goal is to promote innovative behaviour. In contrast to the welfare approach, which considers consumer and producer surplus, the innovation approach to valuing the public domain is concerned mainly with research and development activities of creators and firms. The role of the public domain in this approach is to allow ideas to be shared to promote an optimal level of investment in innovation. If the public domain is too small, innovation may be harmed as a result of firms being unable to sequentially build on existing ideas. If it is too large, innovation may be stifled by a lack of appropriability and lower resultant investment in research by firms.

\section{Public interest justification for the public domain}

A third approach to assessing the value of the public domain in policy is to consider how it contributes to the public interest. In this approach, the informational commons aspects of the public domain are emphasized, although they may coexist alongside economic aspects (e.g. freedom of commercial speech in maintaining competitive markets or the general benefit to society of science and the arts).

Firth (2008) has analysed the legal concept of the public interest in relation to intellectual property, finding its precise definition 'murky', owing to its status as a counterbalance to other rights, such as those granted by copyright law (2008: 427). The public interest is balanced against intellectual property rights in two main ways. First, by granting an additional right, such as a right to freedom of expression or a right to privacy, a specific feature of the public interest may be recognised. Article 10 of the European Convention on Human Rights establishes the right to freedom of expression, including 'freedom to hold opinions and to receive and impart information and ideas without interference by public authority and regardless of frontiers'. ${ }^{4}$ Copyright law itself is also balanced against a broad conception of the public interest in access to information (Davies 2002; Craig 2006). These balancing mechanisms include limitations on the scope and term of protection and exceptions for certain uses of works such as parody, quotation, criticism and review.

Kretschmer (2014) has analysed the role of economic and public interest arguments in specific copyright reform debates (parody, private copying and the use of orphan works). One justification for limiting copyright in cases of parody is to permit freedom of expression, because parody as an artistic practice enables political speech directed at political and commercial targets; whereas from an economic welfare perspective, such policy reform might be grounded in an anticipated increase in derivative products that would have previously been missing due to a failure to transact between copyright holder and parodist. A private copying 
exception, which permits consumers to make limited copies of copyright material for personal use, can be justified in the public interest because it concerns activity which happens in the private sphere, beyond the reasonable purview of state authority. On the other hand, economic analyses of private copying focus on its contribution to market efficiency as a source of information about new tastes and products.

There are a range of public interest reasons for safeguarding and expanding a copyright public domain. It can enable consumers of media to shift roles to coproduce, critique and remix political speech; it can promote media literacy by giving educators and learners opportunity to access and transform expressive works; it can contribute to the legitimacy of the rule of law and intellectual property (by bringing the law in line with everyday practices); and it can promote intercultural understanding by constituting a reservoir of imagined collective history.

Table 1 summarises contrasting policy definitions of the copyright public domain according to the three approaches discussed in the preceding sections.

Table 1: definition and role of public domain under three approaches:

\begin{tabular}{|l|l|l|}
\hline \multicolumn{1}{|c|}{ Approach } & \multicolumn{1}{|c|}{ Policy objectives } & Role of public domain \\
\hline Economic welfare & $\begin{array}{l}\text { Quantity of new } \\
\text { expression; investment in } \\
\text { production; access to } \\
\text { goods }\end{array}$ & $\begin{array}{l}\text { Reduce cost of creative } \\
\text { production to optimal } \\
\text { level, e.g. incentivise new } \\
\text { works. }\end{array}$ \\
\hline Innovation & $\begin{array}{l}\text { Firm/industry structure; } \\
\text { sectoral growth; regional/ } \\
\text { national competitiveness }\end{array}$ & $\begin{array}{l}\text { Provide market } \\
\text { opportunities for firms, } \\
\text { e.g. by reducing R\&D } \\
\text { costs or transaction costs. }\end{array}$ \\
\hline Public interest & $\begin{array}{l}\text { Fair and equitable access } \\
\text { to information; increased } \\
\text { democratic participation; } \\
\text { promotion of science and } \\
\text { arts }\end{array}$ & $\begin{array}{l}\text { Be readily and freely } \\
\text { accessible to all; } \\
\text { heterogeneously } \\
\text { composed; autonomous }\end{array}$ \\
\hline
\end{tabular}

To summarise, an economic welfare justification for the public domain is to increase the quantity of new expressions by reducing the cost of follow-on creativity (as outlined in Landes \& Posner 1989). The public domain cannot expand too much, or it will reduce overall incentives to invest (even if it increases consumption). Overall public access to creative goods is considered, by recognising that the legal monopoly creates deadweight loss; however the primary objective for Landes \& Posner is incentivising new creative production. The shape of the public domain in this approach is determined by judgment about the optimal level of access and borrowing which should be permitted in order to maximally stimulate new creativity. Allowing straight copying of a work without some form or compensation is generally not considered to provide a welfare-optimal solution, as it eliminates incentives to invest. Consequently the public domain is limited to the 
portions of creative works which are not covered by the monopoly right granted to creators, these being reserved to encourage future commercial investment.

The innovation approach to the public domain is focused on improving the rate of generation of new ideas and their application to economic activity. The public domain plays a role in shaping industry structure (for example, by encouraging vertical integration as a response to low appropriability, see Teece 1986; or by enabling new market entrants through opening standards, see Lecocq \& Demil 2006), and therefore may be used as a policy instrument to stimulate innovation. The ability of local, regional, or national firms to access and generate value from ideas in the public domain also becomes a policy objective, which may be pursued using tools such as knowledge exchange, subsidies, industry norms or new IP rights. There are two main rationales for increasing the size of the public domain to achieve innovation objectives: (i) to reduce transaction costs imposed by burdensome private rights, which may allow for more efficient transaction leading to new product development and (ii) to encourage growth in a sector as a result of network effects or other dynamics, for example through promotion of industrywide interoperability standards. In the innovation approach, the most important users of the public domain are innovators, and consequently policy is focused on commercial uptake and use. Non-commercial users may benefit from innovation policies which expand the public domain (for example if their permitted re-use can be captured in a business model), but consumer access and re-use are not policy aims in themselves.

Public interest justifications for the public domain understand its integral role in enabling access to information, increasing political participation and advancing general knowledge. In liberal democracies the objective of such a public domain is to enable informed participation in the political process in an equitable way. The public domain may also serve to promote shared consensus on ethical or moral values, or constitute a reservoir of an imagined collective history. In order to achieve these varied purposes, such a public domain must be freely and readily available to all users, thus comprising both commercial and non-commercial expressions and uses. It should be heterogeneously composed, meaning that contributions to it are not made based on selective criteria, e.g. market valuation. To fulfil a meaningful purpose as an information commons, a public domain should be autonomous from political or market interests. When necessary, policy should intervene in support of each of these objectives, for example by establishing mechanisms to facilitate access (which may include technological or legal tools); shielding the public domain from private interests through legal mechanisms (e.g. limiting new IP rights in reproductions of public domain artwork or public data); and ensuring that its contents are representative of all voices in society and can be readily retrieved and used by all (e.g. by establishing or supporting initiatives like the Europeana Collections and Wikimedia Commons).

The tension between promoting economic incentives and the public interest in copyright law is similar to - and overlaps with - the challenge of regulating broadcast media to promote pluralism. Society broadly recognizes that broadcast media are important in many dimensions: they reach a mass public and can therefore influence politics; they perform an important informational public service, for example in times of crisis; they carry content which reflects the values of those groups who produce it; and they require upkeep of infrastructure owned and 
operated by a range of stakeholders. It is unlikely that all policy objectives can be achieved through application of a private market logic since the incentive to invest, for instance in emergency preparedness or obscure political content, is low. Harrison and Woods (2007) have characterised European broadcast policy as being pulled in two directions, one towards a conception of the audience-as-citizen and the other towards a market conception of audience-as-consumer. The implications of these two conceptions for setting the aims of broadcast regulation result in a vastly different set of approaches:

The consumer resides in the commercial domain, is market-based, economically determined, individualistic and regards content, in all forms, as capable of being purchased and owned. The citizen resides in the public domain and regards certain content as a social and civic asset which should be available to all, sees communication infrastructures as adding to the cultural fabric of collective identity and belonging [...] and believes that the public purse, and not the personal purse, bears the cost of such a service. (Harrison \& Woods 2007: 316)

An approach to regulating the media in the public interest would seek to ensure that programming is of high quality, original and educational. The state might further regulate content to enforce minimum standards in relation to taste, decency and morality. Public interest and economic rationales are not always mutually exclusive or antagonistic - for example, the creation and maintenance of competition in pursuit of a freer market is not necessarily in conflict with a citizen-focused approach if the former results in a diversity of content from different providers. However, the focus of attention in both approaches is different and will likely lead to divergent policy outcomes.

\section{Conclusions}

Supplying economic evidence on the value of the public domain is one significant way that academics can influence intellectual property policy. However, in the same way that market-based approaches to media regulation may fail to adequately promote the needs of a democratic society, so economic definitions of the public domain on their own may not satisfy the normative goals of ensuring access to information and freedom of expression. There are two main ways in which economic approaches to the public domain may need to be augmented. First, there are some functions of the public domain which fall beyond the ability of economists to measure and account for in economic terms. For example, estimating a welfare increase of USD \$208M per annum for Wikipedia helps communicate to lawmakers that the public domain should be acknowledged as a source of benefit equal to other large commercial online information providers and encouraged appropriately. It is less clear how to calculate the welfare effects of a platform like Wikileaks, which does not have an obvious link to the 'creative economy', but nevertheless plays a role in the public political process. Second, there are some dimensions of the public domain which can be valued in economic terms but should not solely be defined that way. In debates about media pluralism, the quantity of expression is not the only metric used by policy makers, as it would form a rather crude measure and could not suffice on its own to ensure that citizenship objectives are met. Similarly, the emphasis on the production of new creative works in welfare economic 
approaches to copyright policy cannot take account of the qualitative aspects of cultural production. How, for example, can one take account of the transgressive character of a remix, which may exceed its market value? There are likewise intrinsic motivations to create and social benefits which spring from the creative process that are difficult to account for, even as inputs to a broader innovation agenda.

The economic basis of copyright will remain central to reform debates. The Berne three-step test, which constrains new EU exceptions to copyright, like the factors used to determine fair use in U.S. copyright law, each balance the public interest with consideration of the potential market for original works. Recent reform efforts, such as the European Parliament's review of the Copyright Directive headed by Julia Reda in 2015, relied in part on economic evidence to support claims. However, in order to produce a balanced IP policy which responds to economic as well as social objectives, additional sources of evidence are needed. Future research could make significant contributions to policy by evidencing the benefits to democracy offered by a free and open public domain.

\section{Acknowledgements}

I am grateful for the constructive comments on early versions of this paper by two economists, Ruth Towse and Theodore Koutmeridis. I would also like to thank the two anonymous reviewers for their helpful comments. Research underlying this paper was supported by the Economic and Social Research Council (ESRC) and UK Intellectual Property Office (UK IPO) grant, 'Valuing the Public Domain' (ES/K008137/1).

\section{Notes}

${ }^{1}$ Directive 96/9/EC of the European Parliament and of the Council of 11 March 1996 on the legal protection of databases.

2 96/9/EC [Art. 7(1)].

3 Directive 2011/77/EU of the European Parliament and of the Council of 27 September 2011 amending Directive 2006/116/EC on the term of protection of copyright and certain related rights.

${ }^{4}$ European Convention on Human Rights (ECHR) [Art. 10(1)]

\section{References}

Alexy, O., Reitzig, M. (2013). Private-collective innovation, competition, and firms' counterintuitive appropriation strategies. Research Policy 42(4): 895-913. http://dx.doi.org/10.1016/j.respol.2013.01.004

Bechtold, S. (2013). The Fashion of TV Show Formats. Michigan State Law Review 2013(2): 451-512.

Bechtold, S., Buccafusco, B. (2015). On the Shoulders of Giants or the Road Less Travelled? An Experimental Approach to Sequential Innovation in Intellectual Property. Paper presented at the European Policy for Intellectual Property (EPIP) conference, Glasgow, UK, 4th September, 2015. 
Bechtold, S., Buccafusco, B., Sprigman, C. (2016 forthcoming). Innovation heuristics: experiments on sequential creativity in intellectual property. Indiana Law Journal (forthcoming 2016): 1-63.

Benkler, Y. (1999). Free as the air to common use: First Amendment constraints on enclosure of the public domain. NYU Law Review 74(2): 354-445. http://dx.doi.org/10.2139/ssrn.168609

Boyle, J. (2003). The second enclosure movement and the construction of the public domain. Law and Contemporary Problems 66(1/2): 33-74. http://dx.doi.org/10.2139/ssrn.470983

Buccafusco, C., Heald, P. (2013). Do Bad Things Happen When Works Enter the Public Domain: Empirical Tests of Copyright Term Extension. Berkeley Technology Law Journal 28: 1-44.

Buccafusco, C., Sprigman, C. (2011). The Creativity Effect. University of Chicago Law Review, 78(1): 31-52.

Craig, C. (2006). Putting the community in communication: Dissolving the conflict between freedom of expression and copyright. University of Toronto Law Journal, 56(1): 75-114. http://dx.doi.org/10.1353/tlj.2006.0002

Davies, G. (2002). Copyright and the public interest. London, UK, Sweet \& Maxwell.

Deazley, R. (2007). Copyright's public domain. In Waelde, C. and MacQueen, H. (Eds.), Intellectual Property: The Many Faces of the Public Domain. Cheltenham, UK, Edward Elgar. http://dx.doi.org/10.4337/9781847 205582.00007

Erickson, K., Heald, P., Homberg, F., Kretschmer, M., Mendis, D. (2015). Copyright and the Value of the Public Domain: An Empirical Assessment. London, UK, Intellectual Property Office.

Firth, A. (2008). 'Holding the line' - The Relationship between the Public Interest and Remedies Granted or Refused, Be It for Breach of Confidence or Copyright. In Torremans, P. (Ed.), Copyright and Human Rights (pp. 421449). Second Edition. Kluwer Law International.

Gowers, A. (2006). Gowers review of intellectual property. London, UK, The Stationery Office.

Hargreaves, I. (2011). Digital Opportunity: A Review of Intellectual Property and Growth: An Independent Report. London, UK, Intellectual Property Office.

Harhoff, D. Henkel, J., Von Hippel, E. (2003). Profiting from voluntary information spillovers: how users benefit by freely revealing their innovations. Research Policy 32(10): 1753-1769. http://dx.doi.org/10.1016/S0048-7333(03)00061-1

Harrison, J., Woods, L. (2007). European Broadcasting Law and Policy. Cambridge, Cambridge University Press. http://dx.doi.org/10.1017/cbo9780511495298

Heald, P. (2014). How Copyright Keeps Works Disappeared. Journal of Empirical Legal Studies, 11(4): 829-866. http://dx.doi.org/10.1111/jels.12057

Heald, P., Erickson, K., Kretschmer, M. (2015). The Valuation of Unprotected Works: A Case Study of Public Domain Photographs on Wikipedia. Harvard Journal of Law and Technology 29(1): 1-37. http://dx.doi.org/10.2139/ ssrn.2560572

Hill, B. M., Monroy-Hernández, A. (2013). The Remixing Dilemma: The Trade-Off Between Generativity and Originality. American Behavioral Scientist 57(5): 643-663. http://dx.doi.org/10.1177/0002764212469359 
Kretschmer, M. (2014). The reasons for copyright takedown on YouTube, and what they tell us about copyright exceptions. Paper presented at the Fair Copyright Workshop, 6-7 January 2014, Tel Aviv University, Tel Aviv.

Landes, W., Posner, R. (1989). An economic analysis of copyright law. The Journal of Legal Studies 18(2): 325-363. http://dx.doi.org/10.1086/468150

Lecocq, X., \& Demil, B. (2006). Strategizing industry structure: the case of open systems in a low-tech industry. Strategic Management Journal, 27(9): 891-898. http://dx.doi.org/10.1002/smj.544

Lessig, L. (2004). Free Culture-the Nature and Future of Creativity. New York, Penguin Books.

Peitz, M., Waelbroeck, P. (2006). Piracy of digital products: A critical review of the theoretical literature. Information Economics and Policy, 18(4): 449-476. http://dx.doi.org/10.1016/j.infoecopol.2006.06.005

Raymond, E. (1998). The cathedral and the bazaar. First Monday, 3(2). http://dx.doi.org/10.1016/0048-7333(86)90027-2

Rose, C. (2003). Romans, roads, and romantic creators: Traditions of public property in the information age, Law and Contemporary Problems 66(1/2), p. 89-110.a

Scotchmer, S. (2004). Innovation and incentives. Cambridge, MA, MIT press.

Teece, D. (1986). Profiting from technological innovation: Implications for integration, collaboration, licensing and public policy. Research Policy 15(6): 285-305. http://dx.doi.org/10.1016/0048-7333(86)90027-2

Towse, R. (2014). Advanced introduction to cultural economics. Cheltenham, UK, Edward Elgar Publishing.

Von Hippel, E., Von Krogh, G. (2003). Open source software and the "privatecollective" innovation model: Issues for organization science. Organization Science 14(2): 209-223. http://dx.doi.org/10.1287/orsc.14.2.209.14992

Yoo, C. S. (2007). Copyright and Public Good Economics: A Misunderstood Relation. University of Pennsylvania Law Review 155(3): 635-715. 